\title{
TINGKAT PENGETAHUAN TB PARU MEMPENGARUHI PENGGUNAAN MASKER PADA PENDERITA TB PARU
}

\author{
Christina Yuliastuti*, Nur Wachida Novita**, Siti Narsih*** \\ Prodi S1, Stikes, Hang Tuah Surabaya Rumkital Dr. Ramelan Surabaya \\ Email : yuliastuti@ hangtuah.ac.id
}

\begin{abstract}
Number of patients with pulmonary TB increased annually in Surabaya, on of the measures to prevent TB infections is by using a mask. In TB care room a lot of visitors (family) who did not wear a mask. The purpose of this study to determine the relationship between the knowledge level of Tuberculose with the masks using among visitors (family). This study used correlational analytic design with cross sectional approach. independent variable in the study is the level of knowledge about Tuberculose and dependent variable is the using of masks. Samples were taken by using simple random sampling technique earned by 28 respondents. Data collection was undertaken using questionnaire about Pulmonary Tuberculose and observation sheet of the using of mask. Data were analyzed with Spearman's Rho test with a significance level Corellation $\rho<0.05$. Results showed that the level of knowledge about Tuberculose less 14 respondents (50\%) and 16 respondents (57.1\%) did not wear a mask. Spearman's Rho test showed that there is a relationship between the level of knowledge about Pulmonary Tuberculose with the using of masks in Pulmonary Wards, Dr. Ramelan Navy Hospital, Surabaya $(\rho=0.000)$. The implications of this study is the level of knowledge about Tuberculosis associated with using of a mask, which is expected for nurses in the room can provide health education about and prevention of pulmonary Tuberculose transmission by using a mask.
\end{abstract}

ABSTRAK : Jumlah penderita TB Paru meningkat tiap tahunnya di Surabaya, salah satu upaya pencegahan penularan infeksi TB adalah dengan menggunakan masker. di ruang perawatan TB banyak pengunjung (keluarga) yang tidak memakai masker. Tujuan penelitian ini untuk mengetahui hubungan tingkat pengetahuan dengan penggunaan masker pada pengunjung (keluarga). Desain penelitian ini adalah analitik korelasional dengan pendekatan cross sectional. Variabel independen dalam penelitian adalah tingkat pengetahuan tentang TB Paru dan variabel dependen adalah penggunaan masker. Sampling dengan simple random sampling sebesar 28 responden. Instrumen menggunakan lembar kuesioner tentang Tuberkulosis Paru dan lembar observasi penggunaan masker. Analisis data yang digunakan uji Spearman's Rho Corellation dengan tingkat kemaknaan $\rho<0,05$. Hasil penelitian menunjukkan bahwa tingkat pengetahuan kurang tentang TB Paru 50\% (14 responden) dan 16 responden $(57,1 \%)$ tidak memakai masker. Hasil uji statistik Spearman's Rho Corellation didapatkan nilai $\rho=0,000 \leq 0,05$ artinya terdapat hubungan antara tingkat pengetahuan tentang TB Paru dengan penggunaan masker di Ruang Paru Rumkital Dr. Ramelan Surabaya. Implikasi penelitian ini adalah tingkat pengetahuan tentang TB Paru berhubungan dengan penggunaan masker, sehingga diharapkan bagi perawat di ruangan dapat memberikan pendidikan kesehatan tentang TB Paru dan upaya pencegahan penularannya dengan menggunakan masker.

Kata kunci : Tingkat Pengetahuan, Tuberkulosis Paru, Masker 


\section{PENDAHULUAN}

Data dari Dinkesprov Jatim tahun 2009 sampai Juni 2012 menunjukkan terjadinya peningkatan jumlah penderita Tuberculosis Paru setiap tahunnya di Surabaya, hal ini memerlukan adanya suatu tindakan terutama tindakan pencegahan untuk mengurangi jumlah kasus TB di masyarakat salah satunya adalah melalui tindakan pencegahan penularan kuman TB Paru dengan menggunakan masker ketika berkontak dengan penderita TB Paru aktif. Penyakit tuberkulosis (TB Paru) merupakan penyakit infeksi menular yang disebabkan oleh Mycobacterium Tuberculosis (Price \& Wilson, 2006 : 852). Penularan Nosokomial M. Tuberkulosis mungkin dapat terjadi diantara pasien TB dengan pengunjung dan perawat yang berkontak erat selama masa perawatan. Tindakan kewaspadaan universal digunakan kepada semua pasien untuk mencegah penularan patogen salah satunya melalui udara seperti Tuberkulosis (Berman et al, 2009: 395). Anjuran penggunaan masker ketika berada dalam jarak 3 kaki dari pasien penderita TB merupakan tindakan kewaspadaaan universal yang perlu dilakukan oleh siapapun yang memiliki kontak erat dengan pasien TB (Kozier, et al, 2010 : 33). Bloom (1908, dalam Sinta, 2012: 129) menyebutkan bahwa pengetahuan atau kognitif merupakan domain yang sangat penting dalam membentuk perilaku seseorang (over behaviour).

Berdasarkan pengalaman klinik dari peneliti ketika berada di Ruang Paru Rumkital Dr. Ramelan Surabaya, peneliti menemukan bahwa beberapa orang yang menjaga pasien TB di ruangan sebagian besar tidak menggunakan masker bahkan terdapat anak kecil yang berada di ruangan pasien TB tidak menggunakan masker saat berada di dekat pasien. Penyebabnya adalah kurangnya pengetahuan mereka tentang penyakit TB Paru dan penularannya. Sejauh ini tingkat pengetahuan tentang TB Paru dengan penggunaan masker sebagai suatu bentuk pecegahan terhadap penularan infeksi TB Paru di Ruang Paru Rumkital Dr. Ramelan Surabaya belum dapat dijelaskan.

WHO memprediksi bahwa terdapat 10, 2 juta kasus baru TB di seluruh dunia (Mandal, 2008: 220). Diperkirakan setiap tahun terdapat 429.720 kasus TB baru dengan kematian sekitar 66.000 orang di Indonesia (Dinkesprov Jatim, 2010). Jumlah Case Detection Rate TB paru di Jawa Timur per Juni 2012 sebesar $32,26 \%$, dengan jumlah kasus TB sebanyak 43.950 penduduk (Dinkesprov Jatim, 2012). Data dari dinas kesehatan Kota Surabaya Jumlah penderita TB di Jawa Timur dari beberapa tahun terakhir yakni tahun (2009) sebanyak 1.216, tahun (2010) sebanyak 3.957, tahun (2011) sebanyak 4812 dan pada tahun (2012) sebnayak 4.493 Warga yang bermukim di Surabaya terkena penyakit infeksi Tuberkulosis (Dinkesprov Jatim). Hasil studi melaporkan Kemungkinan setiap kontak untuk tertular TB paru adalah $17 \%$ dan kontak terdekat (misalnya keluarga serumah) akan dua kali lebih beresiko dibandingkan kontak biasa (tidak serumah) (Widoyono, 2011: 16). Hasil penelitian sebelumnya yang dilakukan oleh Suwarsono, Nurhayati, dan Sayono (2003), tentang kejadian suspek TB pada petugas kesehatan yang tidak 
memakai masker menunjukkan dari 57 orang responden, 47 orang yang tidak memakai masker 2 diantaranya suspek TB. Hasil survei pravelensi TB pada tahun 2004 menegenai pengetahuan, sikap dan perilaku menunjukkan bahwa hanya $51 \%$ keluarga yang memahami cara penularan TB sisanya $49 \%$ keluarga tidak mengetahui cara penularan TB (Kemenkes, 2011 : 14).

Studi pendahuluan yang dilakukan peneliti di Ruang Paru Rumkital Dr. Ramelan Surabaya dari observasi langsung pada tanggal 30 April - 1 Mei 2013 dengan melakukan wawancara kepada 5 orang yang menjaga pasien TB Paru yang berada di Ruang Paru Rumkital Dr. Ramelan Surabaya didapatkan data dari 5 orang yang diwawancarai 4 orang $(80 \%)$ tidak menggunakan masker dengan alasan tidak mengetahui tentang penyakit menular yang ada di ruang paru dan manfaat penggunaan masker dan hanya 1 orang (20\%) yang menggunakan masker.

Individu dapat terinfeksi kuman Tuberkulosis ketika seorang penderita TB berbicara, batuk, bersin, tertawa atau bernyanyi yang dapat melepaskan droplet besar (lebih besar dari $100 \mu$ ) dan kecil (1 sampai $5 \mu$ ). Droplet yang besar akan menetap, sementara droplet yang kecil tertahan di udara (Droplet Nuclei) dan tehirup oleh individu yang beresiko rentan (Suddarth \& Brunner, 2002 : 584 - 585). Orangorang yang beresiko terpajan dengan basil Tuberkulosis adalah mereka yang tinggal berdekatan dengan orang yang terinfeksi aktif. Kelompok ini antara lain, tunawisma yang tinggal ditempat penampungan yang terdapat kasus tuberkulosa, serta anggota keluarga pasien dan petugas kesehatan (Corwin, 2009 : 546). Faktor pencegahan penularan menitikberatkan pada penanggulangan faktor risiko penyakit seperti lingkungan dan perilaku. perilaku seseorang merupakan akumulasi dari pengetahuan dan sikap terhadap kesehatan (Widoyono, 2012: 8). Seseorang yang menjaga pasien TB (misalnya keluarga) merupakan orang yang memiliki riwayat kontak yang erat dengan pasien TB artinya jika mereka tidak mengetahui tentang TB dan tidak menggunakan masker saat di dekat pasien kemungkinan tertular sangat besar mengingat resiko terinfeksi berhubungan dengan lama kontak dan kualitas paparan terhadap sumber infeksi (Widoyono, 2012). Sebaliknya, jika mereka mengetahui dan menggunakan masker saat di dekat pasien kemungkinan tertular akan berkurang karena fungsi masker yang dapat memfiltrasi udara yang dihirup sebelum masuk ke saluran pernafasan manusia (Wijayakusuma, 2003).

Pengetahuan tentang penyakit TB Paru merupakan hal yang sangat penting agar tidak menimbulkan peningkatan jumlah kasus TB Paru akibat penularan dari pasien kepada orang lain, sehingga perlunya seseorang mendapatkan informasi tentang TB dan pencegahannya. Perawat dapat memberikan Health Education berupa informasi langsung atau melalui pemberitahuan tertulis berupa poster tentang cara penularan TB dan pencegahannya. Berdasarkan latar belakang $\mathrm{di}$ atas peneliti mencoba untuk meneliti lebih lanjut tentang hubungan tingkat pengetahuan tentang penyakit TB Paru dengan penggunaan masker di 


\begin{tabular}{lcc}
\hline SMP/sederajat & 10 & 35,7 \\
SMA/sederajat & 13 & 46,4 \\
Akademik/PT & 5 & 17,9 \\
\hline Jumlah & 28 & 100 \\
\hline
\end{tabular}

Berdasarkan tabel 5.3 didapatkan hasil dari 28 responden di Ruang Paru Rumkital Dr. Ramelan Surabaya adalah SMA atau sederajat sebanyak 13 responden $(46,4 \%)$, SMP atau sederajat sebanyak 10 responden $(35,7 \%)$ dan akademik atau perguruan tinggi sebanyak 5 responden $(17,9 \%)$.

\section{Karakteristik Responden Berdasarkan Pekerjaan}

Tabel 5.4 Karakteristik Responden Berdasarkan Pekerjaan Pengunjung (Keluarga) yang Menjaga Pasien TB Paru di Ruang Paru Rumkital Dr. Ramelan Surabaya Pada Tanggal 11 - 20 Juni 2013

\begin{tabular}{lcc}
\hline Pekerjaan & F & $\%$ \\
\hline Pelajar/Mahasiswa & 3 & 10,7 \\
Swasta/Wiraswasta & 10 & 35,7 \\
PNS & 2 & 7,1 \\
TNI / Polri & 3 & 10,7 \\
Tidak Bekerja & 10 & 35,7 \\
\hline Jumlah & 28 & 100 \\
\hline
\end{tabular}

Berdasarkan tabel 5.4 didapatkan hasil dari 28 responden di Ruang Paru Rumkital Dr. Ramelan Surabaya adalah Swasta atau Wiraswasta sebanyak 10 responden $(35,7 \%)$, tidak bekerja sebanyak 10 responden $(35,7 \%)$, PNS sebanyak 2 responden $(7,1 \%)$, Pelajar atau Mahasiswa sebanyak 3 responden $(10,7 \%)$ dan TNI / Polri sebanyak 3 responden $(10,7 \%)$.

\section{Karakteristik Responden Berdasarkan Penghasilan}

Tabel 5.5 Karakteristik Responden Berdasarkan Penghasilan Pengunjung (Keluarga) yang Menjaga Pasien TB Paru di Ruang Paru Rumkital Dr. Ramelan Surabaya Pada Tanggal 11 - 20 Juni 2013

\begin{tabular}{lcc}
\hline Penghasilan & F & $\%$ \\
\hline Tidak Berpenghasilan & 9 & 32,1 \\
$500.000-1.000 .000$ & 6 & 21,4 \\
$1.000 .000-2.000 .000$ & 6 & 21,4 \\
$>2.000 .000$ & 7 & 25,0 \\
\hline Jumlah & 28 & 100 \\
\hline
\end{tabular}

Berdasarkan tabel 5.5 didapatkan hasil dari 28 responden di Ruang Paru Rumkital Dr. Ramelan Surabaya adalah tidak berpenghasilan sebanyak 9 responden $(32,1 \%)$, $500.000-1.000 .000$ sebanyak 6 responden $(21,4 \%), \quad 1.000 .000$ 2.000 .000 sebanyak 6 responden $(21,4 \%)$ dan $>2.000 .000$ sebanyak 7 responden $(25,0 \%)$.
6. Karekteristik Responden Berdasarkan Hubungan Dengan Pasien

Tabel 5.6 Karakteristik Responden Berdasarkan hubungan dengan pasien Pada Pengunjung (Keluarga) yang Menjaga Pasien TB Paru di Ruang Paru Rumkital Dr. Ramelan Surabaya Pada Tanggal 11 - 20 Juni 2013

\begin{tabular}{lcc}
\hline Hubungan dg Pasien & F & $\%$ \\
\hline Suami / Istri & 7 & 25,0 \\
Anak & 8 & 28,6 \\
Ayah / ibu & 8 & 28,6 \\
Kakak / Adik & 3 & 10,7 \\
Paman / Keponakan & 1 & 3,6 \\
Teman & 1 & 3,6 \\
\hline Jumlah & 28 & 100 \\
\hline
\end{tabular}

Berdasarkan tabel 5.6 didapatkan hasil dari 28 responden di Ruang Paru Rumkital Dr. Ramelan Surabaya adalah anak sebanyak 8 responden (28,6\%), ayah / ibu sebanyak 8 responden $(28,6 \%)$, suami / istri sebanyak 7 responden $(25,0 \%)$, kakak / adik sebanyak 3 responden 
$(10,7 \%)$, paman / keponakan sebanyak 1 responden $(3,6 \%)$, dan teman sebanyak 1 responden $(3,6 \%)$.

\section{Karakteristik Responden Berdasarkan Tempat Tinggal}

Tabel 5.7 Karakteristik Responden Berdasarkan Tempat Tinggal Pengunjung (Keluarga) yang Menjaga Pasien TB Paru di Ruang Paru Rumkital Dr. Ramelan Surabaya Pada Tanggal 11 - 20 Juni 2013

\begin{tabular}{lcc}
\hline Tempat Tinggal & F & $\%$ \\
\hline Serumah dengan Pasien & 22 & 78,6 \\
Tidak Serumah & 6 & 21,4 \\
\hline Jumlah & 28 & 100 \\
\hline
\end{tabular}

Berdasarkan tabel 5.7 didapatkan hasil dari 28 responden di Ruang Paru Rumkital Dr. Ramelan Surabaya adalah serumah dengan pasien sebanyak 22 responden $(78,6 \%)$ dan tidak serumah dengan pasien sebanyak 6 responden $(21,4 \%)$.

\section{Karakteristik Responden Berdasarkan Frekuensi Mengunjungi Atau Menjaga Pasien}

Tabel 5.8 Karakteristik Responden Berdasarkan Frekuensi mengunjungi atau menjaga pasien Oleh Pengunjung (Keluarga) yang Menjaga Pasien TB Paru di Ruang Paru Rumkital Dr. Ramelan Surabaya Pada Tanggal 11 - 20 Juni 2013

\begin{tabular}{lcc}
\hline Frek Menjaga Pasien & F & $\%$ \\
\hline Sering/setiaphari & 24 & 85,7 \\
Jarang & 2 & 7,1 \\
Baru kali ini & 2 & 7,1 \\
\hline Jumlah & 28 & 100 \\
\hline
\end{tabular}

Berdasarkan tabel 5.8 didapatkan hasil dari di Ruang Paru Rumkital Dr. Ramelan Surabaya adalah sering atau setiap hari sebanyak 24 responden $(85,7 \%)$, jarang sebanyak 2 responden $(7,1 \%)$, dan baru kali ini sebanyak 2 responden $(7,1 \%)$.

9. Karakteristik Responden Berdasarkan Informasi Tentang TB Paru

Tabel 5.9 Karakteristik Responden Berdasarkan Informasi Tentang TB Paru Pada Pengunjung (Keluarga) yang Menjaga Pasien TB Paru di Ruang Paru Rumkital Dr. Ramelan Surabaya Pada Tanggal 11 - 20 Juni 2013

\begin{tabular}{lcc}
\hline Informasi TB Paru & F & $\%$ \\
\hline Pernah & 12 & 42,9 \\
Belum Pernah & 16 & 57,1 \\
& & \\
\hline Jumlah & 28 & 100 \\
\hline
\end{tabular}

Berdasarkan tabel 5.9 didapatkan hasil dari 28 responden di Ruang Paru Rumkital Dr. Ramelan Surabaya adalah pernah mendapat informasi tentang TB Paru sebanyak 12 responden $(42,9 \%)$ dan belum pernah mendapat informasi tentang TB Paru sebanyak 16 responden $(57,1 \%)$.

Tabel 5.10 Karakteristik Responden Berdasarkan Sumber Informasi Tentang TB Paru Pada Pengunjung (Keluarga) yang Menjaga Pasien TB Paru di Ruang Paru Rumkital Dr. Ramelan Surabaya Pada Tanggal 11 - 20 Juni 2013

\begin{tabular}{lcc}
\hline Sumber Informasi & F & $\%$ \\
\hline Tidak Ada & 16 & 57,1 \\
Media Cetak & 3 & 10,7 \\
Media Elektronik & 2 & 7,1 \\
Kader/petugas kes. & 7 & 25,0 \\
\hline Jumlah & 28 & 100 \\
\hline
\end{tabular}

Sumber informasi berdasarkan tabel 5.10 didapatkan hasil dari 28 
responden sebanyak 3 responden $(10,7 \%)$ mendapat informasi tentang TB Paru dari media cetak, 2 responden $\quad(7,1 \%) \quad$ mendapat informasi dari media elektronik dan 7 responden $(25,0 \%)$ mendapat informasi dari kader atau petugas kesehatan.

\section{Data Khusus}
1. Tingkat Pengetahuan Tentang TB Paru

Tabel 5.11 Frekuensi Tingkat Pengetahuan Pengunjung (Keluarga) yang Menjaga Pasien TB Paru Tentang TB Paru di Ruang Paru Rumkital Dr. Ramelan Surabaya Pada Tanggal 11 - 20 Juni 2013

\begin{tabular}{lcc}
\hline Tingkat Pengetahuan & F & $\%$ \\
\hline Baik & 4 & 14,3 \\
Cukup & 10 & 35,7 \\
Kurang & 14 & 50,0 \\
\hline Jumlah & 28 & 100
\end{tabular}

Berdasarkan tabel 5.11 didapatkan hasil dari 28 responden yang memiliki tingkat pengetahuan memiliki tingkat pengetahuan kurang sebanyak 14 responden (50\%), yang memiliki tingkat pengetahuan cukup sebanyak 10 responden $(35,7 \%)$, dan yang memiliki pengetahuan baik sebanyak 4 responden $(14,3 \%)$.

\section{Penggunaan Masker pengunjung (keluarga)}

Tabel 5.12 Frekuensi Penggunaan Masker Pengunjung (Keluarga) yang Menjaga Pasien TB Paru di Ruang Paru Rumkital Dr. Ramelan Surabaya Pada Tanggal 11 - 20 Juni 2013

\begin{tabular}{llc}
\hline Penggunaan masker & F & $\%$ \\
\hline Memakai masker benar & 2 & 7,1 \\
Memakai kurang benar & 10 & 35,7 \\
Tdk memakai masker & 16 & 57,1 \\
\hline
\end{tabular}

\begin{tabular}{lll}
\hline Jumlah & 28 & 100
\end{tabular}

Berdasarkan tabel 5.12 dari 28 responden didapatkan hasil 16 responden $(57,1 \%)$ tidak memakai masker, 10 responden $(35,7 \%)$ memakai masker tapi kurang benar dan 2 responden $(7,1 \%)$ memakai masker dan benar.

3. Hubungan Tingkat Pengetahuan Tentang TB Paru dengan Penggunaan Masker

Tabel 5.13 Tabulasi Silang Tingkat Pengetahuan Tentang TB Paru dan Penggunaan Masker Pada Pengunjung (Keluarga) Yang Menjaga Pasien TB Paru di Ruang Paru Rumkital Dr. Ramelan Surabaya Pada Tanggal 11 - 20 Juni 2013

\begin{tabular}{lcccccccc}
\hline & \multicolumn{9}{c}{ Penggunaan masker } & \multirow{2}{*}{ Jumlah } \\
\cline { 2 - 7 } Pengetahuan & $\begin{array}{c}\text { Memakai } \\
\text { benar }\end{array}$ & $\begin{array}{c}\text { kurang } \\
\text { benar }\end{array}$ & $\begin{array}{c}\text { Tidak } \\
\text { memakai }\end{array}$ & & \\
\cline { 2 - 7 } & $\mathrm{F}$ & $\%$ & $\mathrm{~F}$ & $\%$ & $\mathrm{~F}$ & $\%$ & $\mathrm{~F}$ & $\%$ \\
\hline Baik & 2 & 50,0 & 2 & 50,0 & 0 & 0,0 & 4 & 100,0 \\
Cukup & 0 & 0,0 & 7 & 70,0 & 3 & 30,0 & 10 & 100,0 \\
Kurang & 0 & 0,0 & 1 & 7,1 & 13 & 92,9 & 14 & 100,0 \\
\hline
\end{tabular}

Spearman's Rho Correlation $\rho=0,000 \quad r=0,775$

Tabel 5.13 menyajikan hubungan antara tingkat pengetahuan tentang TB Paru dengan penggunaan masker di Ruang Paru Rumkital Dr. Ramelan Surabaya pada 28 responden. Berdasarkan 4 responden yang memiliki pengetahuan yang baik menunjukkan penggunaan masker dan benar adalah sebanyak 2 responden (50\%), sebanyak 2 responden $(50 \%)$ menunjukkan penggunaan masker namun kurang benar. Berdasarkan 10 Responden yang memiliki pengetahuan cukup sebanyak 7 responden $\quad(70 \%)$ menunjukkan penggunaan masker namun kurang benar, sebanyak 3 responden $(30 \%)$ tidak menggunakan masker dan tidak ada responden 
dengan pengetahuan cukup yang menggunakan masker dengan benar. Berdasarkan 14 responden yang memiliki pengetahuan kurang sebanyak $13(92,9 \%)$ responden tidak menggunakan masker, 1 responden $(7,1 \%)$ menunjukkan penggunaan masker namun kurang benar dan tidak ada responden dengan pengetahuan kurang yang menggunakan masker dan benar. Hasil uji statistik dengan menggunakan uji Spearman's Rho Correlations $\rho=0,000$. Hal tersebut menunjukkan bahwa $\rho \leq 0,05$ berarti terdapat hubungan antara tingkat pengetahuan tentang TB Paru dengan penggunaan masker di Ruang Paru Rumkital Dr. Ramelan Surabaya. Nilai correlation coefficient yang didapatkan nilai $r=0,775$, itu berarti terdapat hubungan yang kuat antara tingkat pengetahuan tentang TB Paru dengan penggunaan masker di Ruang Paru Rumkital Dr. Ramelan Surabaya.

\section{PEMBAHASAN}

1. Tingkat Pengetahuan tentang TB Paru

Tabel 5.11 menunjukkan dari 28 responden yang memiliki tingkat pengetahuan kurang tentang TB Paru sebanyak 14 responden (50\%), sebanyak 10 responden memiliki pengetahuan cukup dan 4 responden $(14,3 \%)$ memiliki pengetahuan baik tentang TB Paru. Mubarrak et al (2005 : 144 - 145) menyebutkan beberapa faktor yang mempengaruhi tingkat pengetahuan antara lain pendidikan, pekerjaan dan umur, dan informasi. Hal tersebut dibuktikan dari 14 responden yang memiliki tingkat pengetahuan kurang sebanyak 11 responden $(78,6 \%)$ berusia $25-60$ tahun. WHO (2007, dalam Ferry \& Makhfudli, 2009) menyebutkan usia
25 - 60 tahun berada dalam batasan usia dewasa. Craik (1997, dalam Santrock, 2002) mengemukakan bahwa daya ingat menurun pada usia dewasa terutama dewasa tengah dan dewasa akhir. Hal ini lebih terjadi ketika memori jangka panjang (long term memory) lebih terlibat daripada memori jangka pendek (short term memory). Daya ingat juga cenderung menurun ketika informasi yang coba diingat adalah informasi yang belum lama disimpan dan jarang digunakan (Riege \& Inman, dalam Santrock 2002). Daya ingat cenderung menurun jika digunakan untuk mengingat (recall) daripada mengenali (recognize) (Mandler, dalam Santrock, 2002). Faktor informasi dirasakan kurang tersedia di Ruang Paru Rumkital Dr. Ramelan Surabaya yang berkaitan dengan TB Paru dan Masker tidak ada. Pengunjung (keluarga) diberikan informasi atau anjuran untuk menggunakan masker oleh perawat ketika pertama kali pasien datang bersama pasien namun tidak dilakukan klarifikasi lanjutan atau kontinyuitas informasi. Peneliti berasumsi Informasi yang diterima secara berulang selain mempermudah dalam mengingat juga membantu seseorang untuk lebih mengenalinya. Pemberian informasi yang jelas dan kontinyu dapat meningkatkan daya ingat seseorang yang masuk usia dewasa yang mulai mengalami penurunan daya ingat.

Tingkat Pengetahuan tentang TB Paru yang kurang juga dapat dilihat dari tingkat pendidikannya, dari 14 responden dengan tingkat pengetahuan kurang sebanyak 9 responden $(64,3 \%)$ berlatar belakang pendidikan terakhir SMP. Latar belakang pendidikan memegang 
peranan penting untuk mencapai tujuan yang diharapkan, menurut Cokroningrat (1998, dalam Nursalam, 2003) menyatakan umumnya semakin tinggi pendidikan seseorang maka makin mudah dalam menerima informasi sehingga semakin banyak pengetahuan yang dimiliki. Peneliti berasumsi bahwa tingkat pendidikan yang rendah akan menghambat penerimaan dan pemahaman terhadap beberapa nilai baru yang diperkenalkan sehingga tingkat pengetahuan yang dimiliki juga akan kurang.

Tingkat pengetahuan seseorang tidak hanya dipengaruhi oleh usia dan tingkat pengetahuan saja, pekerjaan juga dapat mempengaruhi tingkat pengetahuan responden dari 14 responden yang memiliki tingkat pengetahuan kurang terdapat 6 responden $(42,9 \%)$ tidak bekerja. Lingkungan pekerjaan dapat menjadikan seseorang memperoleh pengalaman baik secara langsung maupun tidak langsung (Dewi \& Wawan, 2011). Peniliti berasumsi bahwa seseorang yang tidak bekerja tingkat pengetahuan yang dimiliki akan kurang bila dibandingkan dengan seseorang yang bekerja, hal ini disebabkan pengetahuan dapat diperoleh dalam dunia bekerja ketika manusia berinteraksi dengan orang lain atau lingkungannya maka akan ada hasil yang didapatkan dari interaksi tersebut misalnya informasi yang dapat menambah pengetahuan seseorang. Dari 14 responden yang memiliki tingkat pengetahuan yang kurang sebanyak 11 responden $(78,6 \%)$ adalah belum pernah mendapat informasi tentang TB Paru. Ilmu pengetahuan dan teknologi membutuhkan informasi, tetapi sekaligus juga menimbulkan informasi. Dengan adanya beragam informasi tentang berbagai cara dalam mencapai pemeliharaan kesehatan, cara menghindari penyakit, maka akan meningkatkan pengetahuan masyarakat tentang hal tersebut (Dewi \& Wawan, 2011 : 18). Sumber informasi yang didapatkan oleh responden berasal dari kader atau petugas kesehatan sebanyak 7 responden $(58,3 \%)$, media elektronik sebanyak 4 responden $(33,3 \%)$ dan media cetak sebanyak 2 responden $(14,3 \%)$. Peneliti berasumsi bahwa semakin banyak seseorang terpapar oleh informasi tentang TB Paru, pengetahuan tentang penyakit atau kesehatan juga akan meningkat. Pemberian informasi tentang penyebab penyakit, gejala dan tanda penyakit, bagaimana cara penularan dan pencegahannya akan membentuk suatu pengetahuan baru yang merupakan indikator dari pengetahuan kesehatan (health knowledge), selain itu peneliti juga berasumsi berdasarkan observasi gambaran umum tempat penelitian bahwa masih kurangnya informasi tentang TB Paru dan manfaat penggunaan masker di ruang paru terlihat dari tidak adanya poster tentang TB Paru dan manfaat penggunaan masker bagi kesehatan hal ini terbukti dari hasil tingkat pengetahuan responden yang sebagian besar tingkat pengetahuan tentang TB Paru adalah kurang.

\section{Penggunaan Masker}

Tabel 5.12 menunjukkan dari 28 responden tidak mengguanakan masker sebanyak 16 responden $(57,1 \%)$, mengunakan masker namun kurang benar sebanyak 10 responden $(35,7 \%)$ dan menggunakan masker benar sebanyak 2 responden $(7,1 \%)$, Hal tersebut dibuktikan 16 responden yang Tidak menggunakan masker 
sebanyak 11 responden $(68,8 \%)$ berjenis kelamin perempuan dan 5 responden $(31,2 \%)$ berjenis kelamin laki - laki. Ameen (2013) dalam bukunya unleash the power of female brain menyebutkan bahwa orang dengan jenis kelamin laki - laki memiliki ukuran lobus parietalis lebih besar dari perempuan. Lobus parietalis berhubungan dengan dunia fisik yang merupakan kontrol impuls terhadap tindakan seseorang, sehingga seseorang dengan jenis kelamin laki - laki cenderung bertindak dahulu beru kemudian memikirkannya sedangkan perempuan cenderung berfikir lama sebelum bertindak, bila dihubungkan dengan teori Menurut Rogers (1947, dalam Notoatmodjo, 2003) tentang teori adaptasi perilaku laki - laki lebih cepat melewati tahap awerness, interest, evaluation, trial, dan adoption dibandingkan dengan perempuan yang lebih lama sehingga perempuan lebih lama mengadopsi suatu perilaku baru, namun hasil jenis kelamintersebut masih belum dikatakan signifikan berpengaruh terhadap penggunaan masker pada responden karena jumlah sampel dalam penelitian memang lebih banyak berjenis kelamin perempuan atau tidak homogen dalam jumlah.

Data yang diperoleh peneliti dari 16 responden yang tidak menggunakan makser sebanyak 14 responden $(87,5 \%)$ berusia $25-60$ tahun (dewasa). Smeltzer \& Bare menyebutkan beberapa faktor demografi yang mempengaruhi kepatuhan seseorang dalam perilaku kesehatan antara lain : usia, jenis kelamin, status sosial ekonomi, dan tingkat pendidikan. Peneliti berasumsi bahwa pada usia dewasa terutama dewasa tengah (paruh baya) sesorang akan mengalami penurunan untuk tingkat pengetahuan mereka dikarenakan penurunan fungsi memori otak yang perlahan mengalami penurunan sehingga indikator untuk mewujudkan suatu perilaku kesehatan seperti memakai masker ketika berada di Ruang Paru sebagai upaya pencegahan terhadap penularan infeksi kuman TB kurang.

Data yang diperoleh peneliti dari 16 responden yang tidak menggunakan masker sebanyak 9 responden $(56,3 \%) \quad$ memiliki pendidikan terakhir SMP. Pendidikan merupakan upaya persuasi atau pembelajaran kepada seseorang agar mau melakukan tindakan - tindakan (praktik) sebagai suatu bentuk perilaku untuk memelihara, mengatasi masalah dan meningkatkan kesehatannya (Notoatmodjo, 2010). Bloom (1908, dalam Notoatmodjo, 2010) menyabutkan bahwa indikator untuk mengukur perilaku kesehatan mengacu pada 3 doamin antara lain pengetahuan terhadap kesehatan, sikap terhadap kesehatan dan praktik kesehatan. Peneliti berasumsi seseorang dengan pendidikan tinggi akan mampu memahami tentang penyakit dan cara pemeliharaan kesehatan terhadap penyakit sehingga penilaian terhadap perilaku kesehatan akan mudah dilakukan.

Responden yang tidak menggunakan masker adalah tidak berpenghasilan, dari 16 responden yang tidak memakai masker sebanyak 7 responden $(43,8 \%)$ adalah tidak berpenghasilan. WHO menganalisis bahwa yang menyebabkan seseorang itu berperilaku tertentu adalah karena beberapa alasan salah satunya adalah karena alasan sumber daya, sumber daya bisa berarti ekonomi atau uang (Notoatmodjo, 2012 : 198). Peneliti berasumsi seseorang yang yang berpenghasilan tinggi akan 
berdampak pada kemampuan daya beli masker sebagai bentuk perilaku kesehatan, namun seseorang yang tidak memiliki penghasilan kemampuan terhadap daya beli masker tidak ada.

Responden yang tidak menggunakan masker dari 16 responden sebanyak 5 responden $(31,3 \%)$ memiliki hubungan suami/ istri dengan pasien. Karr (dalam Notoatmodjo, 2010) menyatakan Adanya otonomi atau kebebasan pribadiuntuk mengambil keputusan dalam melakukan tindakan merupakan salah satu determinan terhadap perilaku kesehatan.peneliti berasumsi bahwa budaya masyarakat indonesia mengenai kebebasan dalam bertindak harus disertai persetujuan dari suami atau kepala keluarga terutama pada masyarakat pedesaan, peneliti melihat bahwa responden yang berstatus sebagai istri pasien memiliki rasa hormat terhadap suami sehingga memiliki rasa "sungkan" untuk memakai masker ketika menjaga suaminya yang sedang sakit. Sehingga responden dengan hubungan sebagai istri pasien TB banyak yang tidak memakai masker.

Responden yang tidak menggunakan masker sebagian besar tinggal serumah dengan pasien, dan frekuensi berkunjung atau menjaga pasien sebagian besar sering atau setiap hari. dari 16 responden yang tidak memakai masker sebanyak 13 responden $(81,3 \%)$ adalah serumah dengan pasien dan berdasarkan karakteristik frekuensi menjaga atau mengunjungi pasien dari 16 responden yang tidak memakai masker sebanyak 13 responden $(81,3 \%)$ adalah sering atau setiap hari. Persepsi seseorang terhadap anggota keluarga yang sakit, tinggal serumah, dan frekuensi dalam menjenguk dapat menjadi suatu stimulus terhadap pembentukan perilaku seseorang. Seseorang yang menganggap kondisi sakit sebagai suatu ancaman (Thread) bagi diri dan kesehatannya akan menjadikan kondisi sakit sebagai suatu stimulus untuk membentuk perilaku kesehatan. Skinner (1908, dalam Notoatmodjo, 2012) Perilaku kesehatan adalah suatu respon seseorang (organisme) terhadap stimulus atau obyek yang berkaitan dengan sakit dan penyakit, sistem pelayanan kesehatan, makanan dan minuman, serta lingkungan. Dari data dan teori yang didapatkan peneliti menarik penjelasan bahwa terdapat ketidaksesuaian antara teori dengan data hal tersebut disebabkan karena selain ada atau tidaknya stimulus dari luar organisme banyak faktor lain yang mempengaruhi perilaku. Green (1980, dalam Notoatmodjo, 2012) mengungkapkan perilaku seseorang dibentuk oleh beberapa faktor antara lain ; faktor predisposisi (pengetahuan, sikap, kepercayaan, tingkat pendidikan, sosial ekonomi), faktor enabling (tersedia atau tidaknya fasilitas atau sarana kesehatan) dan faktor reinforcing (sikap dan perilaku petugas). Peneliti berasumsi seseorang yang menganggap kondisi sakit sebagai suatu stimulus atau obyek belum tentu akan berperilaku terhadap kesehatan jika tanpa adanya dukungan dari ketiga faktor tersebut.

Data yang diperoleh peneliti responden yang tidak menggunakan masker sebagian besar yang belum pernah mendapat informasi tentang TB Paru dan masker. Hal tersebut dapat dibuktikan dari 16 responden yang tidak memakai masker sebanyak 12 responden $(75 \%)$ belum pernah mendapatkan informasi tentang TB Paru dan masker. Kar (dalam 
Notoatmodjo, 2012) menganalisis adanya sumber informasi (accessebility of information) tentang kesehatan merupakan salah satu tolak ukur seseorang dalam membentuk perilaku kesehatan. Peneliti berasumsi bahwa sumber informasi tentang kesehatan dapat dijadikan sebagai pertimbangan seseorang sebelum mewujudkan perilaku kesehatan. Hal tersebut terbukti dari hasil penelitian sebagian besar responden yang tidak menggunakan masker belum pernah mendapat informasi tentang TB Paru dan masker karena dari observasi peneliti terhadap gambaran umum tempat penelitian belum terdapat adanya media informasi seperti poster yang dapat meningkatkan pengetahuan responden selanjutnya dari pengetahuan tersebut akan menimbulkan kesadaran mereka dan akhirnya akan menyebabkan orang berperilaku sesuai dengan pengetahuan yang dimilikinya.

\section{Hubungan Tingkat Pengetahuan Tentang TB Paru dengan Penggunaan Masker \\ Tabel 5.13 menunjukkan dari} 28 responden dari 14 responden yang memiliki pengetahuan kurang tentang TB Paru sebanyak 13 responden $(92,9 \%)$ tidak menggunakan masker, kondisi tersebut dapat membahayakan dan meningkatkan resiko peningkatan kejadian infeksi nosokomial (penularan infeksi TB) akibat perilaku tidak memakai masker dan penggunaan masker yang kurang benar. Greeen (1980, dalam Notoatmodjo, 2012) menyebutkan perilaku dibentuk atau ditentukan dari tiga faktor antara lain faktor predisposisi (predisposing factor) yaitu faktor yang mempermudah terjadinya perilaku seseorang yang terdiri dari pengetahuan, sikap, kepercayaan, tingkat pendidikan, sosial ekonomi; faktor pendukung (enabling factor) yaitu faktor yang memungkinkan atau faktor yang memfasilitasi perilaku atau tindakan yang terdiri dari tersedia atau tidaknya fasilitas atau sarana kesehatan; dan faktor pendorong (reinforcing factor) yaitu faktor yang mendukung atau meperkuat terjadinya perilaku yang terdiri dari sikap dan perilaku petugas.

Dalam mengendalikan infeksi nosokomial di Rumah sakit ada tiga hal yang perlu dilakukan sebagai upaya pengendalian terhadap infeksi nosokomial seperti pencegahan terhadap infeksi penyakit TB Paru antara lain ; (1) adanya surveilan yang mantap yaitu suatu tindakan pengamatan yang sistemik yang dilakukan terus menerus terhadap populasi yang beresiko rentan terhadap penularan penyakit infeksi TB Paru antara lain pengunjung (keluarga) yang menjaga pasien TB Paru di ruangan. Pelaksanaan surveilan ini dilakukan langsung oleh perawat yang berada di ruangan dengan melakukan pengawasan yang dilakukan terus menerus terhadap perilaku pengunjung tentang penggunaan masker saat berada di ruang perawatan, (2) adanya peraturan yang jelas dan tegas tentang pencegahan infeksi nosokomial dilakukan untuk megurangi resiko terjadinya infeksi, (3) adanya program pendidikan kesehatan yang terus menerus bagi pengunjung atau keluarga yang menjaga pasien maupun petugas tentang pencegahan infeksi nosokomial (Septiari, 2012 : 49).

Data diatas menunjukkan bahwa tingkat pengetahuan yang kurang pada responden mendorong 
responden berperilaku negatif terhadap upaya pencegahan penyakit dengan tidak menggunakan masker saat menjaga atau mengunjungi pasien TB Paru di Ruang Paru Rumkital Dr. Ramelan Surabaya. Berdasarkan observasi yang dilakukan peneliti didapatkan belum adanya informasi tentang TB Paru dan penggunaan masker seperti pemberitahuan tertulis (seperti poster) di Ruang Paru Rumkital Dr. Ramelan surabaya, tidak adanya aturan yang jelas dan tegas terhadap penggunaan masker saat berada di ruang perawatan menyebabkan perilaku penggunaan masker ketika menjaga pasien TB Paru juga kurang. McGovern (2000) menjelaskan bahwa pengunjung yang berada dalam ruangan perawatan yang mendapatkan pendidikan kesehatan tentang penyakit infeksi menular dan manfaat penggunaan APD masker memiliki peluang 5,7 kali lebih patuh dalam menggunakan APD saat menjaga pasien. Peneliti berasumsi bahwa pendidikan kesehatan perlu dilakukan secara terus menerus dan kontinyu kepada pengunjung (keluarga) yang menjaga pasien TB Paru ketika menjaga pasien sebagai pembentuk perilaku kepatuhan dalam berperilaku kesehatan pencegahan terhadap infeksi penyakit menular. Observasi peneliti selama penelitian di ruangan mendapatkan pendidikan kesehatan belum terlihat dilakukan, hal tersebut akan berpengaruh pada tingkat pengetahuan pengunjung dan tingkat kepatuhan dalam penggunaan masker.

\begin{tabular}{lrr}
\multicolumn{2}{c}{ Hasil wawancara peneliti } \\
dengan beberapa responden \\
memperoleh & hasil & tidak \\
disediakannya masker secara gratis di \\
ruangan merupakan salah satu \\
penyebab & pengunjung & tidak
\end{tabular}

menggunakan masker, walaupun ada yang menggunakan masker responden akan menggunakan masker tersebut sepanjang hari bahkan disimpan untuk dipakai lagi keesokan harinya, ada pula pengunjung yang mengatakan masker akan dibawa pulang untuk dicuci dan digunakan kembali. Petugas kesehatan di ruangan juga terlihat masih ada yang belum menggunakan masker, selain faktor tingkat pengetahuan yang kurang yang menyebabkan perilaku tidak menggunakan masker pada pengunjung (keluarga) yang menjaga pasien TB Paru di Ruang Paru Rumkital Dr. Ramelan Surabaya yang merupakan Predisposing Factor dari pembentuk perilaku, belum adanya sarana dan prasarana ketersediaan masker khusus bagi pengunjung yang merupakan Enabling Factor, juga masih terdapat petugas kesehatan yang belum menggunakan masker di ruangan tersebut yang merupakan Reinforcing Factor bagi terbentuknya suatu perilaku kesehatan. Petugas kesehatan terutama perawat merupakan Role Model yang dapat dijadikan contoh bagi orang awam dalam memahami masalah kesehatan, apabila petugas kesehatan belum menggunakan masker maka pengunjung (keluarga) sebagai orang awam juga akan enggan untuk menggunakan masker karena menganggap petugas kesehatan yang tahu tentang penyakit saja tidak menggunakan masker, hal tersebut dapat menurunkan kekhawatiran pengunjung terhadap penularan infeksi TB Paru ketika di ruangan sehingga mendorong mereka untuk ikut tidak menggunakan masker. Ketiga faktor tersebut baik secara langsung maupun tidak langsung berperan dalam pembentukan perilaku terutama perilaku kesehatan 
sebagai upaya pencegahan dan perlindungan terhadap penyakit TB Paru dengan penggunaan masker ketika menjaga atau ketika berada di dekat pasien TB Paru di Ruang Paru Rumkital Dr. Ramelan Surabaya.

Responden yang memiliki tingkat pengetahuan yang baik dari 4 responden sebanyak 2 responden $(50 \%)$ memakai masker namun kurang benar, hasil tersebut menunjukkan bahwa tingkat pengetahuan responden yang baik tidak sejalan dengan perilaku penggunaan masker sebagi upaya terhadap pencegahan terhadap infeksi TB Paru. Hal tersebut menunjukkan bahwa responden hanya mengetahui saja namun belum bisa mengaplikasikannya, hal ini sesuia dengan teori bloom (dalam Notoatmodjo, 2003) yang menyatakan bahwa domain pengetahuan berawat dari tahu hingga domain aplikasi. Domain tahu hanya mengetahui tentang prinsip penyakit dan pencegahannya namun belum bisa menerapkannya. Program pendidikan kesehatan hendaknya tidak hanya ditekankan pada aspek penyakit dan perawatannya namun juga aspek edimeiologi dari penyakit tersebut serta upaya pencegahannya (Septiari, 2012) peneliti berasumsi bahwa tingkat pengetahuan yang baik dari responden belum tentu menjadikan responden memiliki perilaku penggunaan masker dengan benar. Responden yang memiliki tingkat pengetahuan yang baik tentang TB Paru menggunakan masker yang kurang benar seperti memakai masker dibongkar pasang dan tidak menutup hidung dan mulut. Pemberian pendidikan kesehatan nantinya tidak hanya tentang TB Paru dan perawatannya namun juga tentang pencegahan infeksi kuman
TB yaitu dengan menggunakan masker dengan baik dan benar.

\section{Simpulan}

Berdasarkan hasil penelitian yang telah oleh peneliti di Ruang Paru Rumkital Dr. Ramelan Surabaya pada tanggal 11 Juni - 20 Juni 2013 dapat ditarik beberapa simpulan sebagai berikut :

1. Tingkat pengetahuan dari pengunjung (keluarga) yang menjaga pasien TB Paru di Ruang Paru Rumkital Dr. Ramelan Surabaya rata - rata kurang.

2. Pengunjung (keluarga) yang menjaga pasien TB Paru di Ruang Paru Rumkital Dr. Ramelan Surabaya sebagian besar tidak memakai masker.

3. Terdapat hubungan antara tingkat pengetahuan tentang TB Paru dengan penggunaan masker di Ruang Paru Rumkital Dr. Ramelan Surabaya.

\section{DAFTAR PUSTAKA}

Ameen, G, (2013). Perbedaan Cara Kerja Otak Pria dan Wanita. http://www.medis.web.id, II 3, diunduh tanggal 25 Juni 2013 jam 23.35 WIB.

Arikunto, S. (2010). Prosedur penelitian suatu pendekatan praktik, edisi revisi 2010. Jakarta : Rineka Cipta.

Berman, A., et al. (2009). Buku Ajar Praktik Keperawatan Klinis, Edisi 5. Jakarta : EGC.

Corwin, E. (2009). Buku Saku Patofisiologi. Jakarta : EGC.

Darmadi. (2008). Infeksi Nosokomial, Problematika dan Pengendaliannya. Jakarta : Salemba Medika. 
Dewi, M. dan Wawan, A. (2011). Teori Dan Pengukuran Pengetahuan, Sikap dan Perilaku Manusia. Yogyakarta : Nuha Medika.

Dinas kesehatan provinsi jawa timur. (2009). Tabel TB Paru Sembuh dan Peneumonia Balita Ditangani di Provinsi Jawa Timur 2009; 10. Jurnal Tabel Profil Kesehatan Jawa Timur 2009.

Dinas kesehatan provinsi jawa timur. (2010). Tabel TB Paru Sembuh dan Peneumonia Balita Ditangani di Provinsi Jawa Timur 2010; 7. Jurnal Tabel Profil Kesehatan Jawa Timur 2010.

Dinas Kesehatan Provinsi Jawa Timur. (2011). Tabel Jumlah Kasus Baru TB Paru dan Kematian Akibat TB Paru Menurut Jenis Kelamin dan Kabupaten / Kota Provinsi Jawa Timur 2011; 10. Jurnal Tabel Profil Kesehatan Jawa Timur 2011.

Dinas Kesehatan Provinsi Jawa Timur. (2012). Program P2 TB september 2012; 16. Program Pengendalian Penyakit Menular di Jawa Timur.

Efendi, F. dan Makhfudli. (2009). Keperawatan Kesehatan Komunitas, Teori dan Praktik dalam Keperawatan. Jakarta : Salemba Medika.

Francis, C. (2011). Perawatan Respirasi. Jakarta : EGC.

Friedman, M., Bowden, R. dan Jones, E. (2010). Buku Ajar Keperawatan Keluarga, Riset, Teori \& Praktik, Edisi 5. Jakarta : EGC.

Kementerian Kesehatan Republik Indonesia Direktorat Jenderal Pengendalian Penyakit Dan Penyehatan Lingkungan. (2011). Stop TB, Terobosan Menuju
Akses Universal Maret 2011; 14. Jurnal Strategi nasional pengendalian $T B$ di indonesia 2010 - 2014

Kozier., et al. (2010). Buku Ajar Fundamental Keperawatan, Konsep, Proses, \& Praktik, Edisi 7, Volume 2. Jakarta : EGC.

Kumar, V., Ramzi, C. dan Stanley, R. (2007). Buku Ajar Patologi. Jakarta : EGC.

Mandal, B., et al. (2008). Penyakit Infeksi, Edisi Keenam. Jakarta : Erlangga.

Mansjoer., et al. (editor). (2009). Kapita Selekta Kedokteran, Edisi 3, Jilid 1. Jakarta : Media Aesculapius.

Martin, U. dan hasibuan, P. (2010). Prevalens TB Laten Pada Petugas Kesehatan di RSUP H. Adam Malik Medan April 2010; Vol 30, No. 2; 112. Jurnal Respir Indo.

Mubarak, W., et al. (2006). Buku Ajar Ilmu Keperawatan Komunitas 2. Jakarta : Sagung Seto.

McGoven, P., Vesley, D., Kochevar. (2000). Factors Affecting Universal Precautions Compliance Januari, 15, 2000, No.200; 149. Journal of Bussiness and Psychology.

Notoatmodjo, S. (2003). Pendidikan dan perilaku kesehatan. Jakarta : Rineka Cipta.

(2010). Promosi Kesehatan Teori \& Aplikasi. Jakarta : Rineka Cipta.

(2011). Kesehatan Masyarakat Ilmu dan Seni. Jakarta : Rineka Cipta.

(2012). Promosi Kesehatan dan Perilaku Kesehatan edisi revisi 2012. Jakarta : Rineka Cipta. 
Nursalam. (2003). Pendidikan dalam Keperawatan. Jakarta : Salemba Medika.

Price, S. dan Wilson, L. (2006). Patofisiologi, Konsep Klinis Proses - Proses Penyakit Edisi 6 Volume 2. Jakarta : EGC.

Potter \& Perry. (2005). Buku Ajar Fundamental Keperawatan, Konsep, Proses dan Praktik, Edisi 4, Volume 1. Jakarta : EGC.

Santrock, J W. (2002). Life Span Development, Perkembangan Masa Hidup. Jakarta : Erlangga.

Septiari, B. (2012). Medical Book Infeksi Nosokomial. Yogyakarta : Nuha Medika.

Sinta, F. (2012). Promosi Kesehatan. Yogyakarta : Graha Ilmu.

Smeltzer, S. dan Bare, B. (2002). Buku Ajar Keperawatan Medikal Bedah Brunner \& Suddarth, Edisi 8, Volume 1. Jakarta : EGC.

Sudoyo, A., et al. (2005). Ilmu Penyakit Dalam, Jilid III, Edisi IV. Jakarta : EGC.

Suwarsono, D., Nurhayati. dan Sayono. (2003). Hubungan Lama Kerja, Bagian Kerja dan Pemakaian Masker Dengan Suspek dan Infeksi Mycobacterium Tuberculosa 2003; Vol No. 1; 47. Jurnal Unimus.

Syamsuhidajat. dan De Jong. (2007). Buku Ajar Ilmu Bedah. Jakarta : EGC.

Widoyono. (2012). Penyakit Tropis Epidemiologi, Penularan, Pencegahan, dan Pemberantasannya, Edisi Kedua. Jakarta : Erlangga.

Wijayakusuma, H. (2003). Proteksi Dini Terhadap SARS (Severe Acute Respiratory Syndrome). Jakarta : Pustaka Populer Obor. 